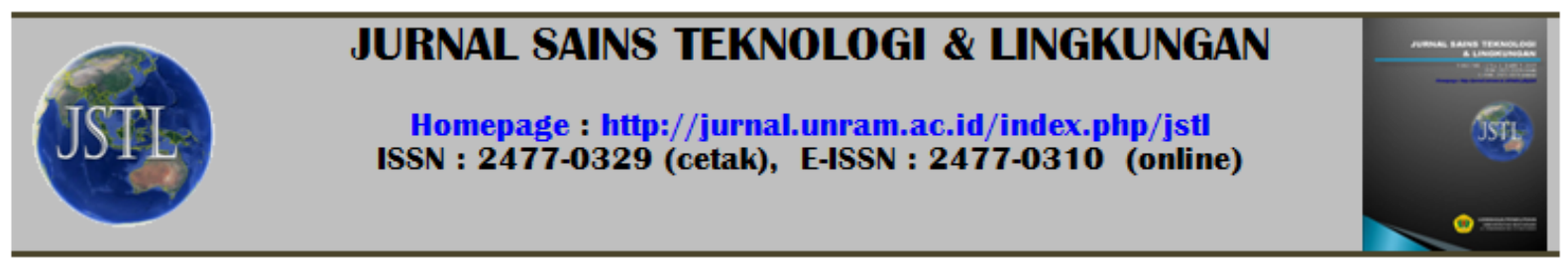

\title{
ANALISIS DEGRADASI LAHAN DAN EVALUASI KESESUAIAN LAHAN HUTAN TANAMAN INDUSTRI DI DESA MARGA KARYA RESORT SEMAMUNG, KPHP BATULANTEH
}

\author{
1) Rato Firdaus Silamon ${ }^{1}$ ) Muhamad Husni Idris , $\left.{ }^{1}\right)$ Surya Anggara \\ 1) Program Studi Kehutanan, Universitas Mataram
}

\begin{tabular}{ll}
\hline Kata kunci : & Abstrak \\
\hline Degradasi lahan, & Pembukaan lahan dan pembalakan liar yang terjadi di kawasan hutan produksi Resort \\
Evaluasi & Semamung, KPHP Batulanteh berdampak terhadap terjadinya degradasi hutan di \\
Kesesuaian Lahan, & wilayah tersebut. Penelitian ini bertujuan untuk mengetahui kelas degradasi lahan dan \\
Kelas Kesesuaian & kesesuaian lahan tanaman industri kehutanan di wilayah tersebut. Penelitian ini \\
Lahan & dilaksanakan pada bulan Maret sampai dengan April 2015. Pendekatan kandungan C- \\
& Organik tanah digunakan untuk menganalisa tingkat degradasi lahan. Sedangkan \\
& pendekatan pencocokan matriks kesesuaian biofisik lahan dan operasi tumpang tindih \\
& terhadap karakteristik keruangan faktor/kriteria kesesuaian digunakan untuk \\
& mengetahui sebaran kelas kesesuaian lahan pada beberapa jenis tanaman kehutanan. \\
& Hasil penelitian menunjukan bahwa degradasi lahan di lokasi penelitian terbagi \\
& kedalam 5 kelas yaitu terdegradasi sangat berat seluas 1,53 ha, terdegradasi berat seluas \\
& 31,8 ha, terdegradasi sedang seluas 24,2 ha, terdegradasi ringan seluas 9,08 ha dan \\
& terdegradasi sangat ringan seluas 0,55 ha. Tanaman Akasia mangium memiliki sebaran \\
& lahan pada ordo sesuai yang tertinggi yaitu mencapai 59 ha atau sebesar $88,06 \%$ dari \\
& total luas area, yang terdistribusi kedalam kelas sangat sesuai (S1) seluas 2 ha, kelas \\
& cukup sesuai (S2) seluas 30 ha, kelas sesuai marjinal (S3) seluas 27 ha, kelas tidak \\
& sesuai saat ini (N1) seluas 6 ha, dan kelas tidak sesuai selamanya (N2) seluas 1 ha
\end{tabular}

\begin{tabular}{ll}
\hline Key words : & Abstract \\
\hline Land degradation, & Land clearing and illegal logging that occured in production forest of Resort \\
Evaluation of Land & Semamung Production Forest Management Unit (KPHP) of Batulanteh has an impact \\
Suitability, Class of & on forest degradation. This study aims to determine classes of land degradation and \\
Land Suitability & land suitability for industrial plantation forest. The study was conducted from March \\
& to April 2015. Analysis on soil organic carbon (C-Organic) was used to determinate \\
& land degradation classes, while matchup matriks of land quality and characteristics \\
& that combined with spatial operations was used to analyze land suitable classes for \\
& various forestry plant. The results showed that land degradation was divided into five \\
& class of categories which is: very high degraded land amounting to 1.53 hectares of \\
& area, high degraded land amounting to 31.8 hectares of area, moderate degraded land \\
& amounting to 24.2 hectares of area, slight low and low degraded land amounting in the \\
& row of 9.08 hectrares and 0.55 hectares of area. Evaluation of land suitability showed \\
& that Acacia mangium has the largest suitable land area amounting to 59 hectares or \\
& equal to $88.06 \%$ of total area of interest (AOI). The suitable ordo devided into five \\
& classes which is: highly suitable (S1) amounting to 2 hectares of area, moderate \\
& suitable (S2) amounting to 30 hectares of area, marginal suitable (S3) amounting to 27 \\
& hectares of area, curently not suitable (N1) amounting to 6 hectares of area, and \\
permanently not suitable amounting to 1 hectares of area
\end{tabular}




\section{PENDAHULUAN}

Permasalahan umum kehutanan Indonesia adalah laju deforestasi dan tingkat degradasi kawasan hutan yang tinggi. Deforestasi umumnya terjadi akibat pengalih peruntukan lahan hutan baik untuk permukiman, perladangan, fasilitas publik dan lain-lain. Degradasi lahan umumnya disebabkan oleh pengelolaan kawasan hutan yang tidak lestari baik oleh pemegang Ijin Usaha Pemanfaatan Hasil Hutan Kayu (IUPHHK) ataupun karena pembalakan yang dilakukan oleh pihak yang tidak memiliki IUPHHK.

KPHP Batulanteh merupakan salah satu KPH model yang terletak di Kabupaten Sumbawa. Sesuai dengan SK Menteri Kehutanan R.I nomor SK. 342/Menhut-II/2011 luas wilayah kelola KPHP Batulanteh adalah sebesar 32.776 Ha. Desa Marga Karya merupakan salah satu desa di Kecamatan Moyo Hulu yang berbatasan langsung dengan wilayah kelola KPHP Batulanteh. Masyarakat mulai masuk ke dalam kawasan semenjak ijin pengelolaan oleh Perum Perhutani habis. Kawasan yang sebelumnya merupakan tegakan hutan mulai berubah peruntukan menjadi perladangan dengan tanaman utama jagung. Dampak dari pengelolaan ini adalah terjadinya degradasi lahan. Penelitian ini dilakukan untuk menganalisis kelas degradasi lahan yang terjadi di wilayah tersebut. Selain itu, penelitian ini juga bertujuan mengevaluasi kesesuaian lahan terhadap beberapa jenis tanaman kehutanan untuk mengetahui jenis tanaman yang tepat dan sesuai secara biofisik untuk dikembangkan pada wilayah tersebut.

\section{METODOLOGI PENELITIAN}

Penelitian dilaksanakan di kawasan hutan produksi Desa Marga Karya, Resort Semamung, KPHP Batulanteh dengan luasan areal studi sebesar $67 \mathrm{Ha}$. Alat yang digunakan dalam penelitian ini adalah unit komputer dan piranti lunaknya (Ms. Office dan Esri ArcGIS 10.2) untuk melakukan analisis data tabular dan spasial, GPS untuk penetapan lokasi pengambilan contoh karakteristik biofisik lahan, dan perlengkapan survey tanah untuk pengambilan contoh tanah. Bahan yang digunakan dalam penelitian ini adalah citra udara, data kontur, peta batas wilayah kawasan hutan KPHP Batulanteh, data rekaman hujan selama 5 tahun dan kriteria kesesuaian lahan tanaman. Kegiatan penelitian diawali dengan menentukan titik pengamatan yang ditentukan secara bebas karena data dasar yang digunakan cukup lengkap (Beckett dan Burrough, 1978). Sampling frame dan sebaran titik pengamatan termuat pada Gambar 1 berikut:

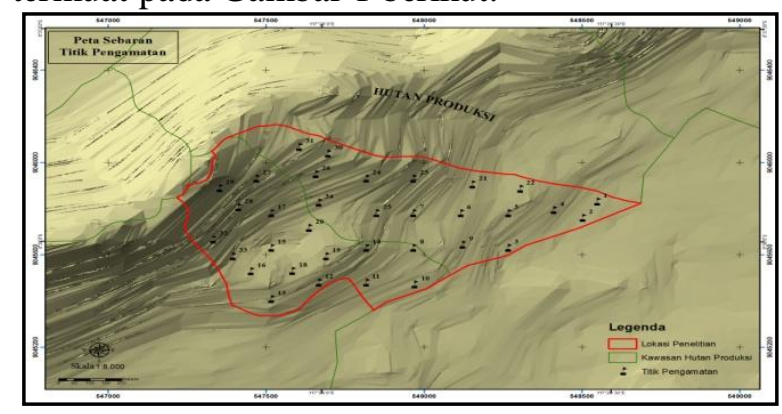

Gambar 1. Peta Sebaran Titik Pengamatan

Parameter yang diamati dalam penelitian ini adalah suhu udara, curah hujan, kedalaman efektif tanah, tekstur tanah, persentase $\mathrm{C}$ organik tanah, persentase batuan dan kelerengnan. Analisis degradasi hutan dilaksanakan dengan mengklasifikasikan persentase $\mathrm{C}$ organik tanah menurut Balai Penelitian Tanah (1993) dalam Hardjowigeno dan Widiatmaka (2007). Berikut pendekatan degradasi lahan berdasarkan persentase $\mathrm{C}$ organik tanah (Tabel 1).

Tabel 1. Tabel Pendekatan Degradasi Lahan

\begin{tabular}{|c|c|c|c|}
\hline No & Interval & $\begin{array}{c}\text { Kelas C } \\
\text { organic }\end{array}$ & $\begin{array}{c}\text { Kelas } \\
\text { Degradasi } \\
\text { Lahan }\end{array}$ \\
\hline 1 & $<1 \%$ & $\begin{array}{c}\text { Sangat } \\
\text { Rendah }\end{array}$ & Sangat Berat \\
\hline 2 & $1-2 \%$ & Rendah & Berat \\
\hline 3 & $2.01-3 \%$ & Sedang & Sedang \\
\hline 4 & $3.01-5 \%$ & Tinggi & Ringan \\
\hline 5 & $>5 \%$ & Sangat Tinggi & Sangat Ringan \\
\hline
\end{tabular}

Evaluasi kesesuaian lahan dilakukan dengan melakukan proses operasi spasial tumpang tindih terhadap peta-peta tematik suhu, curah hujan, tekstur tanah, kedalaman efektif tanah, C-Organik, batuan permukaan, batuan tersingkap dan kelerengan lahan. Kemudian, dilakukan pencocokan antara kriteria tumbuh tanaman dengan karakteristik eksisting lahan. Kriteria tanaman yang digunakan dalam penelitian ini adalah kriteria berdasarkan Pusat Penelitian Tanah (PPT). 


\section{HASIL DAN PEMBAHASAN \\ Karakteristik Lahan}

Tekstur tanah di lokasi penelitian terbagi ke dalam kelas tekstur Lempung Berpasir (SL) pada luasan 49 ha, Pasir Berlempung (LS) 8 ha, Lempung (L) 3 ha dan Liat Lempung Berpasir (SCL) 6 ha. Kedalaman efektif tanah di lokasi penelitian tersebar dari 7,54 cm sampai dengan $88,09 \mathrm{~cm}$.

Curah hujan di daerah penelitian ditentukan dengan menggunakan data rekaman dari satelit TRMM (Tropical Rainfall Measurement Mission) menggunakan 5 tahun data yaitu dari tahun 2010 sampai dengan tahun 2014, yang selanjutnya didapatkan curah hujan rata-rata tahunan sebesar 1497,60 mm/tahun. Data suhu udara lokasi penelitian diperoleh dari kegiatan pengukuran langsung dilapangan dengan menggunakan alat pencatat suhu Termometer. Suhu tertinggi di lokasi penelitian adalah $30,9^{\circ} \mathrm{C}$ dan terendah adalah $26^{\circ} \mathrm{C}$.

Persen batuan permukaan di lokasi penelitian terbagi kedalam interval $<3 \%$ dengan luas 31 Ha, 3-15\% 19 Ha, 15-40\% 15 Ha dan >40$44.1980 .6 \mathrm{Ha}$. Sementara itu, persen batuan tersingkap terbagi atas 1.35-2\% dengan luas 25 $\mathrm{Ha},>2-10 \% 17 \mathrm{Ha},>10-25 \% 9 \mathrm{Ha},>25-40 \% 6$ Ha dan $>40-71.39 \% 8 \mathrm{Ha}$

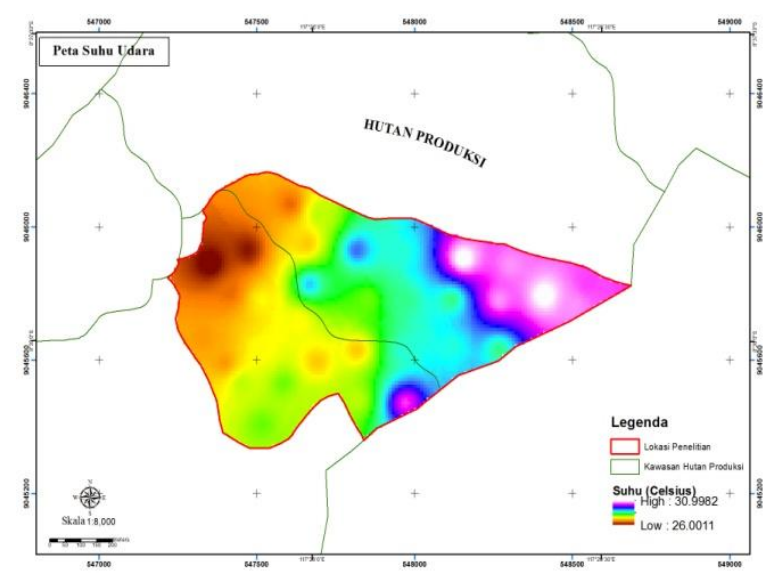

(A)

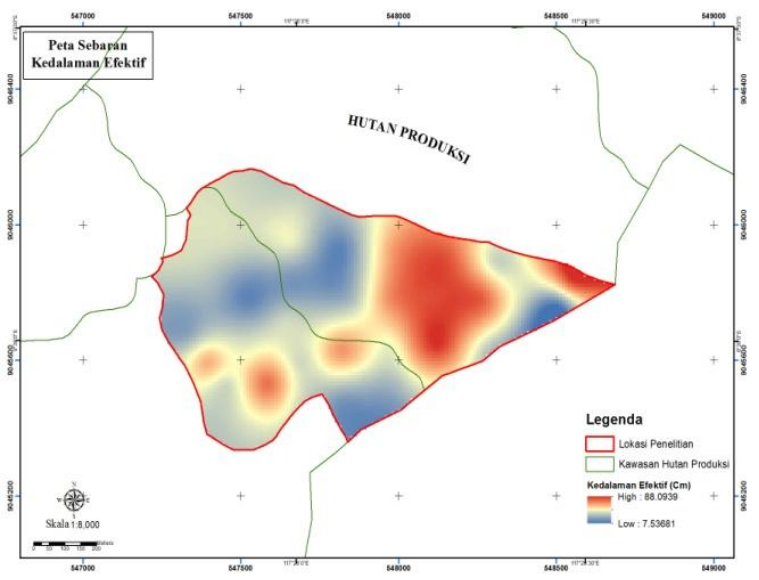

(B)

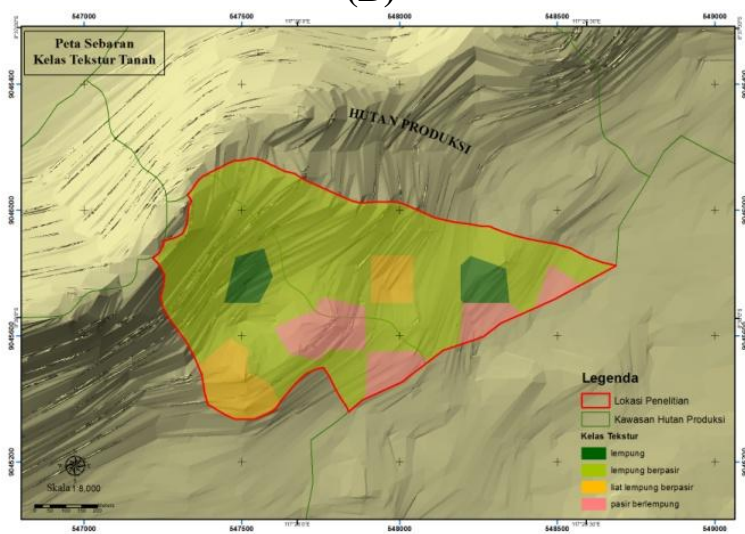

(C)

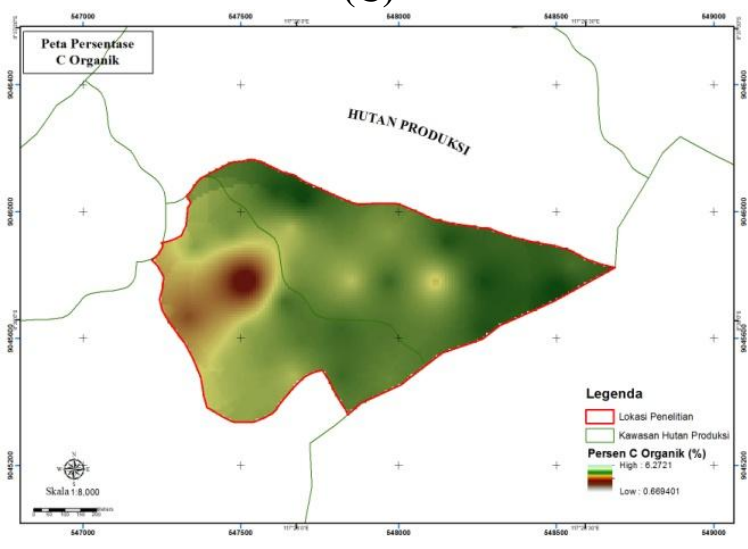

(D)

Gambar 2. Peta Karakteristik Lahan Lokasi Penelitian

Keterangan Gambar:

A: Peta sebaran kelas suhu udara pada lokasi penelitian

B: Peta sebaran kedalaman efektif solum tanah pada lokasi penelitian

C: Peta sebaran kelas tekstur tanah pada lokasi penelitian

D: Peta sebaran perbandingan nisbah C-Organik pada lokasi penelitian 


\section{C-Organik Tanah dan Tutupan Lahan}

Terdapat 3 (tiga) tipe tutupan lahan di lokasi penelitian yakni lahan hutan, lahan bekas penebangan dan lahan perladangan. Berdasarkan matrik degradasi lahan dengan pendekatan kandungan C-Organik tanah (Tabel 1), menunjukkan bahwa tutupan lahan hutan terindikasi sebagai wilayah dengan tingkat degradasi ringan dengan rata-rata kadar COrganik tanah sebesar 3,36\%. Lahan bekas penebangan (log over area) terindikasi ke dalam kelas degradasi sedang dengan indeks rata-rata kadar C-Organik tanah sebesar 2,01\%. Adapun halnya dengan lahan perladangan terindikasi berada pada kelas degradasi lahan berat dengan indeks rata-rata kadar C-Organik tanah sebesar $1,42 \%$. Tingginya kadar C-Organik tanah pada tutupan lahan hutan dapat dipahami sebagai akibat dari tingginya kelimpahan vegetasi tutupan lahan yang mampu mensuplai karbon ke dalam tanah secara terus menerus. Vegetasi merupakan sumber utama C-Organik tanah. Semakin beragamnya jenis vegetasi, maka bentang lahan tersebut berpeluang memiliki persentase C-Organik yang tinggi (Collins et al., 1999). Konversi lahan hutan menjadi lahan perladangan menyebabkan penurunan persentase C-Organik tanah 1,94\%. Persentase C-Organik tanah sangat rentan terhadap perubahan seperti akibat konversi vegetasi penutup lahan (Sabaruddin et al., 2009) dan panen (Mroz et al, 1985). Panen dalam hal ini dapat dimaknai sebagai kegiatan pemanenan kayu legal, ataupun kegiatan pemanenan kayu yang dilakukan secara ilegal

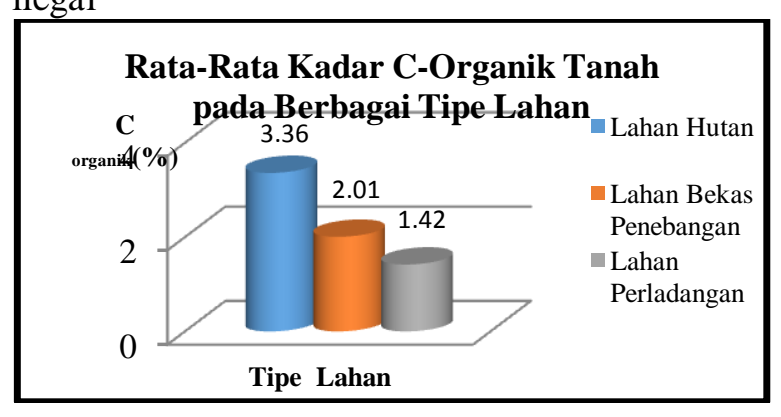

Gambar 3. Perbandingan Rata-rata Kadar C Organik pada Tipe Tutupan Lahan

\section{C-Organik Tanah dan Kemiringan Lahan}

Terdapat 6 kelas kemiringan lahan di lokasi penelitian, meliputi kemiringan <3\%, kemiringan 3-8\%, 8-15\%, 15-30\%, 30-50\%, dan $>50 \%$. Menurut Arsyad (2000), dengan semakin curamnya lereng maka aliran permukaan akan semakin besar dimana tanah yang banyak mengandung bahan organik akan turut terangkut dan terbawa ke tempat yang lebih rendah. Berbeda dengan teori yang diungkapkan oleh Arsyad di atas, temuan di lapangan menunjukkan bahwasanya terdapat kecenderungan hubungan berbanding lurus antara kemiringan lahan dengan rata-rata kandungan C-Organik tanah, dimana semakin curam lahan menunjukkan semakin tingginya kandungan C-Organik tanah. Rata-rata kandungan C-Organik tanah tertinggi ditemukan pada lahan-lahan dengan kemiringan 30-50\% $(3,46 \%)$, sedangkan Rata-rata kandungan COrganik tanah terendah ditemukan pada lahanlahan dengan kemiringan 3-8\% (1,20\%). Dari temuan tersebut dapat dipahami bahwa kemiringan lahan secara kualitatif tidak memiliki pengaruh langsung yang signifikan terhadap kandungan C-Organik tanah apabila terdapat perbedaan formasi tutupan lahan pada setiap kelas kemiringan lahan. Hal tersebut turut diperkuat dari data pada Tabel 2 yang menunjukkan bahwa lahan-lahan di lokasi penelitian dengan kemiringan $>30 \%$ umumnya memiliki formasi tutupan lahan berhutan dengan jenis-jenis tanaman dominan seperti Ketimus (Protium javanicum Burm.F) dan Talok (Schoutenia ovate Kurtz) dengan produktivitas serasah yang tinggi. Sedangkan pada lahanlahan dengan kemiringan $<30 \%$ umumnya berupa lahan-lahan dengan formasi tutupan lahan perladangan dan areal bekas tebangan yang didominasi oleh tanaman semusim seperti Jagung (Zea mays) dan beberapa tanaman keras pada fase pertumbuhan pancang yang menyebar tidak beraturan seperti Johar (Cassia siamea), Akasia (Acacia mangium), dan Kapuk (Ceiba pentandra).

Tabel 2. Persentase $\mathrm{C}$ organik pada Kelas Kelerengan

\begin{tabular}{|c|c|c|c|c|c|c|}
\hline \multirow{2}{*}{ Uraian } & \multicolumn{6}{|c|}{ Kelas Kemiringan Lahan } \\
\hline & $<3 \%$ & $3.8 \%$ & $8.15 \%$ & $15 \cdot 30 \%$ & $30.50 \%$ & $>50 \%$ \\
\hline $\begin{array}{l}\text { Rata-rata Kandungan C-Organik } \\
\text { Tanah }\end{array}$ & 1,49 & 1,20 & 1,77 & 2.50 & 3.46 & 2.31 \\
\hline $\begin{array}{l}\text { Formasi Tutupan Lahan } \\
\text { Dominan }\end{array}$ & Perladangan & Perladangan & $\begin{array}{c}\text { Areal } \\
\text { bekas } \\
\text { tebangan }\end{array}$ & Hutan & Hutan & Hutan \\
\hline Vegetasi dominan & Jagung & Jagung & $\begin{array}{l}\text { Jati dan } \\
\text { Akasia } \\
\text { (fase } \\
\text { pancang) }\end{array}$ & $\begin{array}{c}\text { Jati, } \\
\text { Akasia, } \\
\text { Johar } \\
\text { (kerapatan } \\
\text { rawang) }\end{array}$ & $\begin{array}{l}\text { Ketimus, } \\
\text { Talok }\end{array}$ & Talok \\
\hline Luas sebaran $\left(\mathrm{m}^{2}\right)$ & 68,71 & 38,53 & 215,11 & 270,40 & 70,43 & 8,80 \\
\hline
\end{tabular}




\section{C-Organik Tanah dan Fraksi Liat}

Analisis varians menunjukkan bahwa fraksi liat memiliki pengaruh tidak langsung yang nyata terhadap perubahan nilai C-Organik tanah pada taraf nyata $5 \%$. Pola hubungan tidak langsung antara fraksi liat tanah dengan kandungan C-Organik tanah pada lokasi penelitian menunjukkan kecenderungan pola berbanding lurus seperti yang terlihat pada Gambar 4. Temuan ini sejalan dengan apa yang diungkapkan oleh Foth (1998) yang menyatakan bahwa terdapat kecenderungan hubungan antara kandungan liat tanah dengan persentase $\mathrm{C}$ Organik, dimana semakin besar kandungan liat maka semakin tinggi persentase C-Organik pada tanah karena molekul-molekul organik yang diadsorpsi oleh liat dilindungi secara parsial dari perombakan oleh mikroorganisme

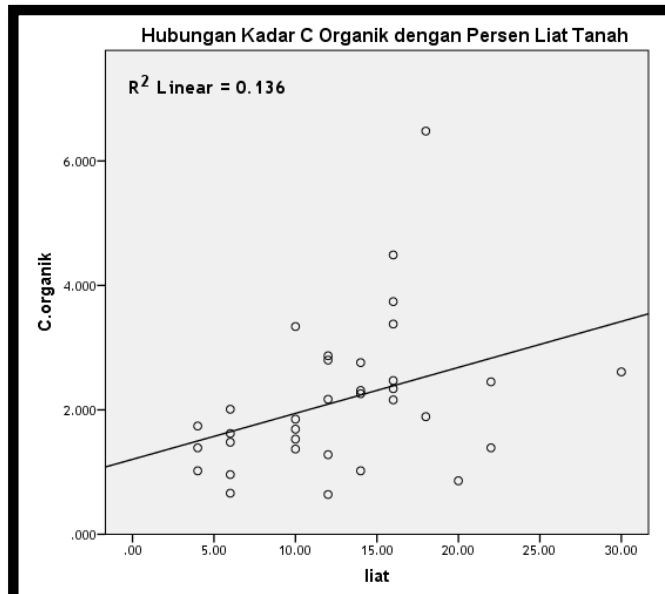

Gambar 4. Pola Hubungan Fraksi Liat dengan C-Organik Tanah

\section{Sebaran Kelas Degradasi Lahan}

Hasil pengolahan data secara tabular dan spasial menunjukkan bahwa pada lokasi penelitian teridentifikasi 5 kelas degradasi yaitu lahan terdegradasi sangat berat seluas 1,53 ha, lahan terdegradasi berat seluas 31,8 ha, lahan terdegradasi sedang seluas 24,2 ha, lahan terdegradasi ringan seluas 9,08 ha dan lahan terdegradasi sangat ringan seluas 0,55 ha.

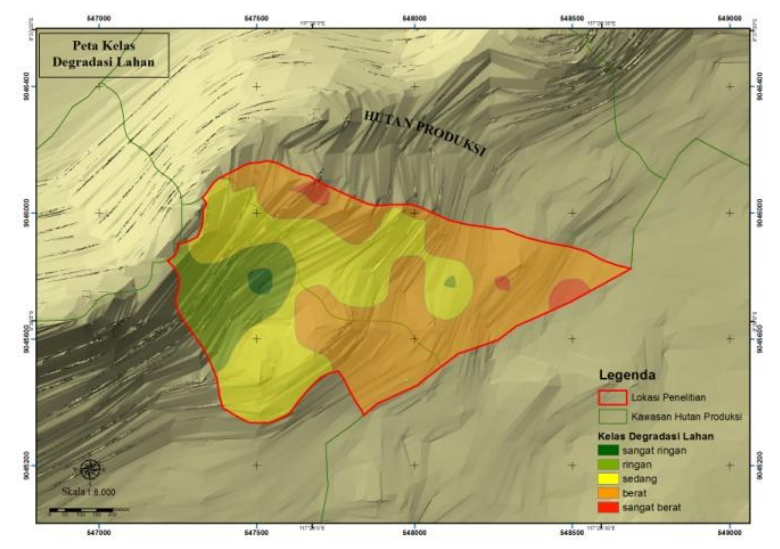

Gambar 5. Peta Degradasi Lahan

\section{Analisis Kesesuaian Lahan Pengembangan Komoditas}

Jati, Akasia, Eucaliptus, dan Kayu Putih merupakan komoditas bisnis utama (core business) yang akan dikembangkan oleh KPHP Batulanteh seperti yang termuat dalam dokumen RPJM KPHP Batulanteh 2013-2022 (Dishut NTB, 2013). Hasil analisis data dengan pendekatan matchup matrik kesesuaian lahan dan operasi spasial pada menunjukkan bahwa di antara keempat tanaman komoditas core business di atas, Akasia memiliki sebaran lahan pada ordo sesuai yang tertinggi yaitu mencapai 59 ha atau sebesar 88,06\% dari total luas area, yang terdistribusi kedalam kelas S1 (sangat sesuai) seluas 2 ha, kelas S2 (cukup sesuai) seluas 30 ha, dan S3 (sesuai marjinal) seluas 27 ha. Informasi tersebut memuat makna bahwasanya tanaman akasia pada lokasi penelitian memiliki peluang untuk dikembangkan selama KPHP Batulanteh mampu melakukan investasi berupa pemberian inputan seperti pengolahan lahan dan silvikultur intensif mengingat tingginya sebaran lahan yang masuk kedalam kategori S2 dan S3 dengan faktor penghambat agak berat sampai sangat berat yang dalam hal ini berupa tekstur tanah, kelerengan lahan, dan curah hujan.

Seiring dengan berjalannya periode pengelolaan dan proses penjaringan need assessment di tingkat masyarakat, terdapat wacana untuk mengembangkan tanaman kehutanan dengan pola tumpang sari dengan tanaman perkebunan dan pertanian seperti jagung pada lokasi penelitian. Hasil analisis kesesuaian lahan untuk komoditas jagung menunjukkan bahwa komoditas tersebut kurang layak secara biofisik untuk dikembangkan pada lokasi penelitian, 
mengingat tidak ditemukan adanya sebaran lahan pada kelas $\mathrm{S} 1$, dan hanya sedikit lahan ditemukan menyebar pada kelas S2 (3 ha), dimana selebihnya menyebar pada kelas S3 (26 ha) dengan faktor pembatas sangat berat dan pada kelas N1 (21 ha), dan N2 (15 ha) yang mengndung makna bahwa faktor pembatas belum dapat di rekayasa dengan ketersediaan teknologi saat ini yang dapat berimplikasi pada fenomena gagal tanam apabila dipaksakan untuk dikembangkan.

Tabel 3.

Luasan pada tiap Kelas Kesesuaian Lahan Tanaman

\begin{tabular}{|c|l|c|c|c|c|c|c|c|}
\hline \multirow{2}{*}{ No } & \multirow{2}{*}{ Jenis Tanaman } & \multicolumn{7}{|c|}{ Ordo dan Kelas Kesesuaian Lahan } \\
\cline { 3 - 9 } & & S (Ha) & S1 (Ha) & S2 (Ha) & S3 (Ha) & N (Ha) & N1 (Ha) & N2 Ha) \\
\hline 1 & Jati & 58 & - & 11 & 47 & 7 & 6 & 1 \\
\hline 2 & Akasia & 59 & 2 & 30 & 27 & 7 & 6 & 1 \\
\hline 3 & Kayu Putih & 53 & 1 & 28 & 24 & 13 & 12 & 1 \\
\hline 4 & Eukaliptus & 53 & - & 29 & 24 & 13 & 12 & 1 \\
\hline 5 & Lamtoro & 53 & 1 & 28 & 24 & 13 & 12 & 1 \\
\hline 6 & Jagung & 29 & - & 3 & 26 & 36 & 21 & 15 \\
\hline
\end{tabular}

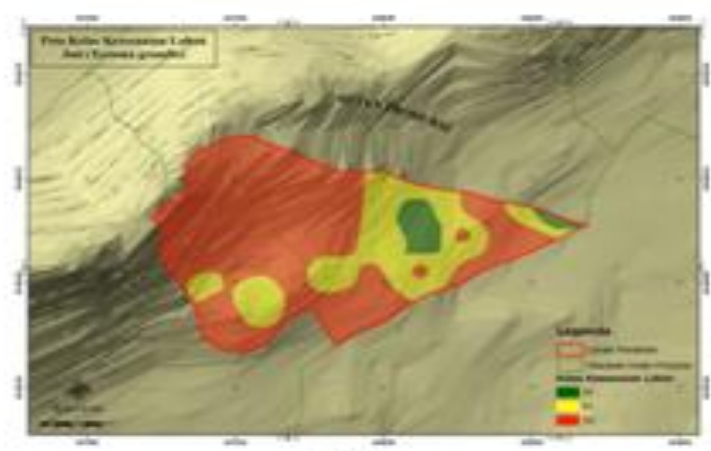

(A)

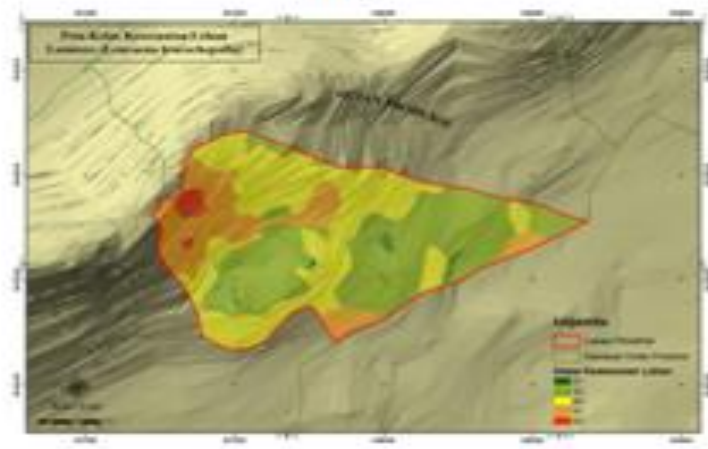

(C)

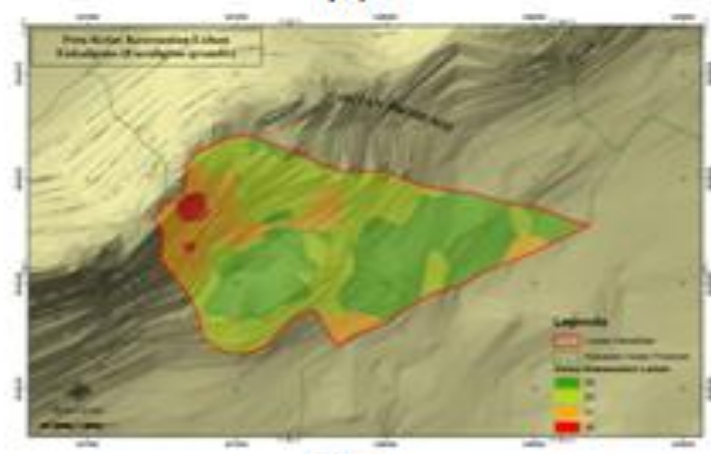

(E)

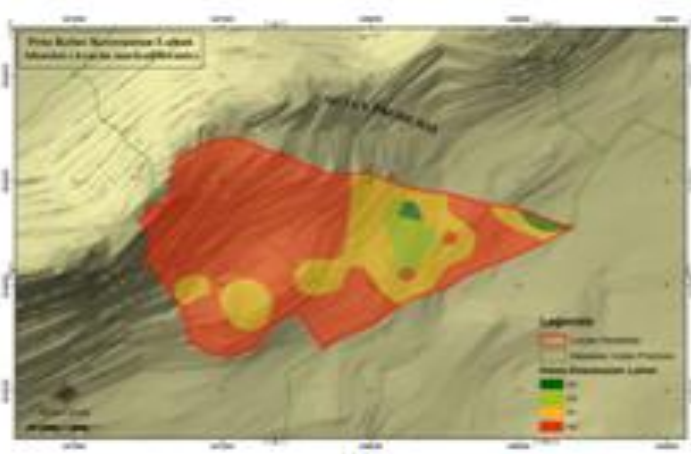

(B)

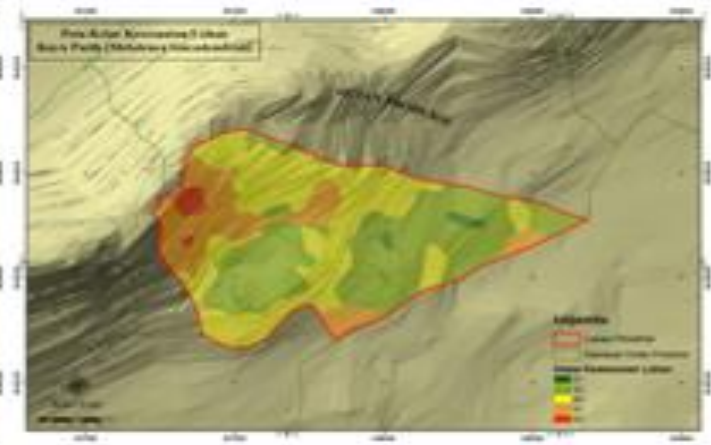

(D)

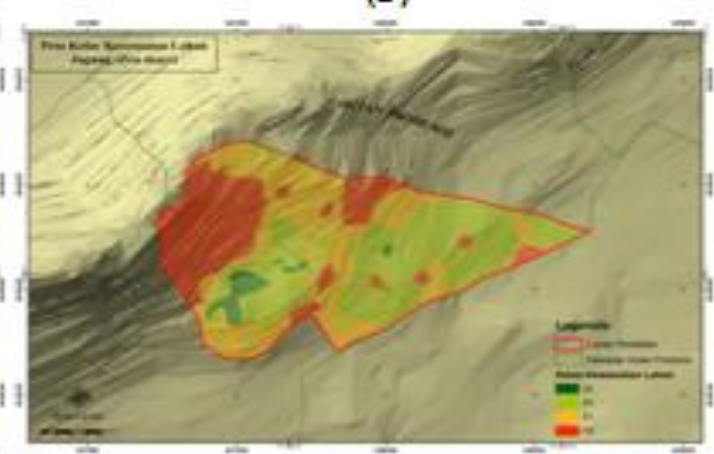

(F)

Gambar 6. Peta Kesesuaian Lahan Berbagai Komoditas Tanaman 
Keterangan Gambar:

A: Peta sebaran kesesuaian lahan Jati (Tectona grandis)

B: Peta sebaran kesesuaian lahan Akasia (Acacia mangium)

C: Peta sebaran kesesuaian lahan Lamtoro

(Leucaena leucochepala)

D: Peta sebaran kesesuaian lahan Kayu Putih

(Melaleuca leucadendron)

E: Peta sebaran kesesuaian lahan Ekaliptus

(Eucaliptus grandis)

F: Peta sebaran kesesuaian lahan Jagung (Zea mays)

\section{KESIMPULAN}

Wilayah kelola KPHP Batulanteh Resort Semamung yang terletak pada Desa Marga Karya telah mengalami penurunan kualitas lingkungan tingkat lanjut, yang diindikasikan oleh tingginya sebaran lahan dengan kategori terdegradasi sedang dan berat berdasarkan pendekatan kandungan C-Organik tanah. Pembuatan tanaman berbasis Akasia, Jati, Kayu Putih, dan Ekaliptus sebagai inti bisnis KPHP Batulanteh memiliki peluang untuk dikembangkan di lokasi penelitian melalui penerapan silvikultur intensif sebagai upaya untuk mengatasi keberadaan faktor pembatas.

\section{DAFTAR PUSTAKA}

Arsyad, S. 2000. Konservasi Tanah dan Air. Institut Pertanian Bogor Press. Bogor.

Beckett, P.H.T. dan Burrough,P.A. 1978. Use of Soil and Land System Maps to Provide Soil Information in Australia. CSIRO Div, Soils Techn. Paper No.33

Collins, H.P., R.L, Bleoins. L.G., Bundy. D.R., Cristenson. W.A., Dick. D.R., Huggins, and T.A., Paul. 1999. Soil Carbon Dynamic in Corn Based Agroecosystem: Result from Carbon 13 Natural Abudance. Soil Science Society America Journal. 63: 584-591.

Dinas Kehutanan Provinsi NTB. 2013. Rencana Pengelolaan Jangka Menengah Kesatuan Pengelolaan Hutan Produksi (KPHP) Batulanteh Tahun 2013-2022. Mataram.

Foth, 1998. Dasar-Dasar Ilmu Tanah. Gadjah Mada University Press, Yogyakarta.

Hardjowigeno, S dan Widiatmaka. 2007. Evaluasi Kesesuaian Lahan dan Perencanaan Tataguna Lahan. Gadjah Mada University Press. Yogyakarta
Mroz, G.D., Jurgensen, M.F. and Frederick, D.J. 1985. Soil Nutrient Changes Following whole Tree Harvesting on Three Northern Hardwood Sites. Soil Science Society of America Journal. 49:1552-1557.

Sabaruddin., Fitri, S.N.A., Lestari, Lesi. 2009. Hubungan antara Kandungan Bahan Organik Tanah dengan Periode Pasca Tebang Tanaman HTI Acacia mangium Willd. Jurnal Tanah Tropika. Vol. 14, No. 2: 105-110. Universitas Lampung. 